\title{
Simultaneous estimation of ramipril, acetylsalicylic acid and atorvastatin calcium by chemometrics assisted UV-spectrophotometric method in capsules
}

\author{
A. S. KAMATCHI SANKAR ${ }^{1 *}$ \\ THANGARASU VETRICHELVAN ${ }^{1}$ \\ DEVASHYA VENKAPPAYA ${ }^{2}$ \\ 1 Adhiparasakthi College of Pharmacy \\ Melmaruvathur-603319, India \\ 2 School of Biotechnology \\ (Shanmuga Arts, Science \\ Technology and Research Academy) \\ SASTRA University \\ Thanjavur-613402, India
}

In the present work, three different spectrophotometric methods for simultaneous estimation of ramipril, aspirin and atorvastatin calcium in raw materials and in formulations are described. Overlapped data was quantitatively resolved by using chemometric methods, viz. inverse least squares (ILS), principal component regression (PCR) and partial least squares (PLS). Calibrations were constructed using the absorption data matrix corresponding to the concentration data matrix. The linearity range was found to be $1-5,10-50$ and $2-10 \mu \mathrm{g} \mathrm{mL}^{-1}$ for ramipril, aspirin and atorvastatin calcium, respectively. The absorbance matrix was obtained by measuring the zero-order absorbance in the wavelength range between 210 and $320 \mathrm{~nm}$. A training set design of the concentration data corresponding to the ramipril, aspirin and atorvastatin calcium mixtures was organized statistically to maximize the information content from the spectra and to minimize the error of multivariate calibrations. By applying the respective algorithms for PLS 1, PCR and ILS to the measured spectra of the calibration set, a suitable model was obtained. This model was selected on the basis of RMSECV and RMSEP values. The same was applied to the prediction set and capsule formulation. Mean recoveries of the commercial formulation set together with the figures of merit (calibration sensitivity, selectivity, limit of detection, limit of quantification and analytical sensitivity) were estimated. Validity of the proposed approaches was successfully assessed for analyses of drugs in the various prepared physical mixtures and formulations.

Keywords: figures of merit, multivariate calibration, ramipril, aspirin, atorvastatin calcium

The greatest difficulties with UV-Vis multi determination methods arise when the analytes to be determined give partly or fully overlapped spectra. Multivariate calibra-

\footnotetext{
* Correspondence; e-mail: asksankar@yahoo.com
} 
tion is a useful tool in the analysis of multicomponent mixtures because it allows rapid and simultaneous determination of each component in the mixture with reasonable accuracy and precision and without the need of lengthy separation procedures. With the aid of modern instrumentation to acquire and digitize spectral information and powerful computers to process large amounts of data, chemometric methods such as classical least squares (CLS), inverse least squares (ILS), principle component regression (PCR) and partial least squares (PLS) regression are finding increasing use in quantitative analysis of complex mixtures, offering an interesting alternative to chromatographic techniques.

Atorvastatin (AT), (3R,5R)-7-[2-(4-fluorophenyl)-3-phenyl-4-(phenylcarbamoyl)-5-(propan-2-yl)-1H-pyrrol-1-yl]-3,5-dihydroxyheptanoic acid, is a synthetic lipid-lowering agent (1). AT is an inhibitor of 3-hydroxy-3-methylglutaryl-coenzyme A reductase. Ramipril (RA), (2S,3aS,6aS)-1-[(2S)-2-\{[(2S)-1-ethoxy-1-oxo-4-phenylbutan-2-yl]amino\}propanoyl]-octahydrocyclopenta[ $b]$ pyrrole-2-carboxylic acid, is an angiotensin converting enzyme inhibitor, used to treat hypertension and congestive heart failure (2). Acetylsalicylic acid (AS) is 2-acetyloxybenzoic acid, often used as an analgesic, antipyretic, anti-inflammatory and antiplatelet agent (3).

Literature survey revealed several analytical methods reported for the determination of AS, AT and RA (4-11) in pharmaceutical dosage forms and biological samples. No method is reported for simultaneous estimation of AT, RA and AS in combined formulations applying chemometrics. Hence, the aim was to develop a selective, sensitive and accurate method for estimating the three components simultaneously.

In recent years, multivariate calibration techniques, such as CLS, ILS, PCR and PLS, started to be applied to the analysis of analytical data obtained in all instrumentations (12). The main advantages of these techniques are the following: higher speed of processing data concerning the values of concentrations and absorbances of compounds with strongly overlapping spectra, errors of the calibration model are minimized by measuring the absorbance values at many points in the wavelength range of zero-order spectra. In this work, laboratory mixtures and capsules containing RA, AS and AT were investigated and resolved by three chemometric methods using zero-order spectra.

\section{EXPERIMENTAL}

\section{Instruments}

A double-beam Shimadzu (Japan) UV-vis spectrophotometer, model UV-2550 PC equipped with 1-cm quartz cells, was used. The bundled software used was UVPC »WINLAB« software version 3.1 (Shimadzu). ILS, PCR and PLS-1 analyses were carried out by using the PLS-Toolbox software version 5.0 (demo) for use with MATLAB 7.0.

\section{Solvent, stock and standard solutions and pharmaceutical formulations}

Methanol was used as the solvent for all the solution preparations, since it was found to be the common solvent for all the three drugs. To prepare stock solutions, $100.0 \mathrm{mg}$ of 
A. S. K. Sankar et al.: Simultaneous estimation of ramipril, acetylsalicylic acid and atorvastatin calcium by chemometrics assisted UV-spectrophotometric method in capsules, Acta Pharm. 61 (2011) 283-296.

Table I. Composition and results of the calibration set by PLS 1, PCR and ILS methods

\begin{tabular}{|c|c|c|c|c|c|c|c|c|c|c|c|c|}
\hline \multirow{3}{*}{ Sample } & \multirow{2}{*}{\multicolumn{3}{|c|}{$\begin{array}{l}\text { Calibration set } \\
\text { concentration } \\
\left(\mu \mathrm{g} \mathrm{mL}^{-1}\right)\end{array}$}} & \multicolumn{9}{|c|}{ Result found ( $\left.\mu \mathrm{g} \mathrm{mL}{ }^{-1}\right)$} \\
\hline & & & & \multicolumn{3}{|c|}{ PLS 1} & \multicolumn{3}{|c|}{ PCR } & \multicolumn{3}{|c|}{ ILS } \\
\hline & RA & AS & AT & RA & AS & AT & RA & AS & $\mathrm{AT}$ & RA & AS & AT \\
\hline 1 & 3 & 30 & 6 & 2.92 & 29.52 & 5.81 & 2.92 & 30.10 & 5.81 & 3.00 & 29.77 & 5.93 \\
\hline 2 & 3 & 10 & 2 & 3.04 & 9.97 & 2.05 & 3.04 & 10.14 & 2.05 & 2.95 & 10.35 & 1.95 \\
\hline 3 & 1 & 10 & 10 & 0.99 & 9.69 & 9.84 & 0.99 & 9.73 & 9.84 & 0.99 & 9.36 & 9.93 \\
\hline 4 & 1 & 50 & 4 & 1.01 & 48.76 & 3.80 & 1.01 & 49.70 & 3.80 & 1.02 & 49.61 & 4.16 \\
\hline 5 & 5 & 20 & 10 & 4.89 & 20.09 & 10.00 & 4.89 & 20.20 & 10.00 & 4.97 & 20.65 & 9.76 \\
\hline 6 & 2 & 50 & 6 & 2.05 & 50.53 & 6.35 & 2.05 & 50.20 & 6.35 & 1.95 & 50.29 & 5.96 \\
\hline 7 & 5 & 30 & 4 & 5.03 & 30.88 & 4.05 & 5.03 & 29.90 & 4.05 & 4.96 & 29.78 & 4.15 \\
\hline 8 & 3 & 20 & 4 & 2.98 & 20.12 & 4.09 & 2.98 & 19.88 & 4.09 & 2.95 & 19.89 & 4.02 \\
\hline 9 & 2 & 20 & 8 & 1.98 & 20.08 & 7.92 & 1.98 & 19.78 & 7.92 & 1.94 & 19.94 & 8.09 \\
\hline 10 & 2 & 40 & 10 & 2.03 & 39.90 & 9.75 & 2.03 & 40.02 & 9.75 & 2.00 & 40.30 & 9.96 \\
\hline 11 & 4 & 50 & 8 & 3.92 & 51.03 & 7.77 & 3.92 & 50.37 & 7.77 & 3.98 & 50.40 & 7.93 \\
\hline 12 & 5 & 40 & 6 & 5.09 & 39.91 & 5.99 & 5.09 & 39.92 & 5.99 & 5.02 & 40.47 & 5.82 \\
\hline 13 & 4 & 30 & 10 & 3.98 & 30.22 & 9.91 & 3.98 & 30.02 & 9.91 & 4.03 & 29.95 & 9.89 \\
\hline 14 & 3 & 50 & 10 & 3.04 & 49.56 & 10.58 & 3.04 & 49.91 & 10.58 & 3.08 & 49.96 & 10.35 \\
\hline 15 & 5 & 50 & 2 & 4.97 & 49.70 & 1.90 & 4.97 & 49.80 & 1.90 & 4.99 & 49.67 & 1.93 \\
\hline 16 & 5 & 10 & 8 & 5.04 & 10.43 & 8.07 & 5.04 & 9.80 & 8.07 & 5.02 & 9.96 & 7.93 \\
\hline 17 & 1 & 40 & 2 & 0.97 & 40.41 & 2.05 & 0.97 & 40.10 & 2.05 & 1.05 & 40.12 & 1.82 \\
\hline 18 & 4 & 10 & 6 & 4.08 & 10.18 & 6.08 & 4.08 & 9.99 & 6.08 & 4.02 & 9.96 & 5.89 \\
\hline 19 & 1 & 30 & 8 & 1.04 & 29.46 & 7.93 & 1.04 & 29.95 & 7.93 & 0.91 & 30.31 & 7.92 \\
\hline 20 & 3 & 40 & 8 & 2.99 & 40.56 & 7.75 & 2.99 & 40.11 & 7.75 & 3.01 & 40.12 & 8.05 \\
\hline 21 & 4 & 40 & 4 & 4.03 & 39.58 & 3.95 & 4.03 & 39.89 & 3.95 & 4.02 & 40.07 & 3.96 \\
\hline 22 & 4 & 20 & 2 & 3.96 & 20.12 & 2.04 & 3.96 & 20.04 & 2.04 & 3.96 & 20.00 & 2.01 \\
\hline 23 & 2 & 10 & 4 & 1.99 & 9.68 & 3.93 & 1.99 & 10.38 & 3.93 & 1.98 & 10.70 & 4.06 \\
\hline 24 & 1 & 20 & 6 & 1.02 & 19.32 & 6.31 & 1.02 & 20.12 & 6.31 & 0.94 & 19.74 & 6.09 \\
\hline 25 & 2 & 30 & 2 & 1.97 & 30.12 & 2.07 & 1.97 & 29.93 & 2.07 & 2.00 & 29.92 & 2.00 \\
\hline
\end{tabular}

RA - ramipril, AS - acetylsalicylic acid, AT - atorvastatin calcium

all the three drugs were weighed separately into a $100-\mathrm{mL}$ standard volumetric flask, dissolved in a few $\mathrm{mL}$ of methanol and finally made up to the volume with the same solvent.

Standard solutions. - Calibration and validation (prediction) set. - A training set of 25 standard mixture solutions containing $1-5,10-50$ and $2-10 \mu \mathrm{g} \mathrm{mL} \mathrm{m}^{-1}$ of RA, AS and AT, respectively, was made daily from stock solutions using methanol as diluent. Also, a validation set of 16 synthetic mixtures containing various concentrations in the range of 1.2-4.8, 12.0-48.0 and 2.5-10.0 $\mu \mathrm{g} \mathrm{mL}^{-1}$ of RA, AS and AT, respectively, was prepared from the same stock solutions to verify the model capability of predicting the synthetic laboratory mixture. Concentration ranges of the calibration and prediction sets are shown in Tables I and II. 
A. S. K. Sankar et al.: Simultaneous estimation of ramipril, acetylsalicylic acid and atorvastatin calcium by chemometrics assisted UV-spectrophotometric method in capsules, Acta Pharm. 61 (2011) 283-296.

Table II. Composition and results of the prediction set by PLS 1, PCR and ILS methods

\begin{tabular}{|c|c|c|c|c|c|c|c|c|c|c|c|c|}
\hline \multirow{3}{*}{ Sample } & \multirow{2}{*}{\multicolumn{3}{|c|}{$\begin{array}{l}\text { Prediction set } \\
\text { concentration } \\
\left(\mu \mathrm{g} \mathrm{mL}^{-1}\right)\end{array}$}} & \multicolumn{9}{|c|}{ Result found $\left(\mu \mathrm{g} \mathrm{mL} L^{-1}\right)$} \\
\hline & & & & \multicolumn{3}{|c|}{ PLS 1} & \multicolumn{3}{|c|}{ PCR } & \multicolumn{3}{|c|}{ ILS } \\
\hline & RA & AS & $\mathrm{AT}$ & RA & AS & AT & RA & AS & AT & RA & AS & $\mathrm{AT}$ \\
\hline 1 & 1.2 & 12 & 2.5 & 1.17 & 11.81 & 2.42 & 1.17 & 12.05 & 2.42 & 1.20 & 11.91 & 2.47 \\
\hline 2 & 1.2 & 24 & 5.0 & 1.21 & 23.94 & 5.13 & 1.22 & 24.36 & 5.14 & 1.18 & 24.84 & 4.87 \\
\hline 3 & 2.4 & 24 & 10.0 & 2.36 & 23.27 & 9.84 & 2.37 & 23.38 & 9.85 & 2.38 & 22.46 & 9.93 \\
\hline 4 & 2.4 & 48 & 5.0 & 2.43 & 46.81 & 4.75 & 2.44 & 47.76 & 4.75 & 2.44 & 47.63 & 5.20 \\
\hline 5 & 4.8 & 24 & 2.5 & 4.69 & 24.11 & 2.50 & 4.70 & 24.27 & 2.50 & 4.77 & 24.77 & 2.44 \\
\hline 6 & 2.4 & 12 & 7.5 & 2.46 & 12.13 & 7.93 & 2.46 & 12.06 & 7.94 & 2.34 & 12.07 & 7.45 \\
\hline 7 & 1.2 & 36 & 7.5 & 1.21 & 37.06 & 7.60 & 1.21 & 35.92 & 7.61 & 1.19 & 35.74 & 7.78 \\
\hline 8 & 3.6 & 36 & 5.0 & 3.58 & 36.22 & 5.11 & 3.58 & 35.83 & 5.12 & 3.54 & 35.80 & 5.02 \\
\hline 9 & 3.6 & 24 & 7.5 & 3.56 & 24.10 & 7.43 & 3.57 & 23.76 & 7.43 & 3.49 & 23.92 & 7.59 \\
\hline 10 & 2.4 & 36 & 2.5 & 2.44 & 35.91 & 2.44 & 2.44 & 36.06 & 2.44 & 2.40 & 36.27 & 2.49 \\
\hline 11 & 3.6 & 12 & 10.0 & 3.53 & 12.25 & 9.72 & 3.53 & 12.10 & 9.73 & 3.58 & 12.10 & 9.91 \\
\hline 12 & 1.2 & 48 & 10.0 & 1.22 & 47.90 & 9.98 & 1.22 & 47.95 & 9.99 & 1.20 & 48.56 & 9.70 \\
\hline 13 & 4.8 & 48 & 7.5 & 4.78 & 48.36 & 7.43 & 4.78 & 48.07 & 7.44 & 4.84 & 47.91 & 7.42 \\
\hline 14 & 4.8 & 36 & 10.0 & 4.86 & 35.68 & 10.58 & 4.86 & 35.97 & 10.59 & 4.93 & 35.97 & 10.35 \\
\hline 15 & 3.6 & 48 & 2.5 & 3.58 & 47.71 & 2.38 & 3.58 & 47.86 & 2.38 & 3.59 & 47.68 & 2.41 \\
\hline 16 & 4.8 & 12 & 5.0 & 4.84 & 12.52 & 5.04 & 4.84 & 11.77 & 5.05 & 4.82 & 11.95 & 4.96 \\
\hline
\end{tabular}

RA - ramipril, AS - acetylsalicylic acid, AT - atorvastatin calcium

Pharmaceutical capsule formulation. - Capsule formulation, Polytorva (containing $5 \mathrm{mg}$ ramipril (RA), $75 \mathrm{mg}$ acetylsalicylic acid (AS) and $10 \mathrm{mg}$ atorvastatin calcium (AT) along with excipients) was analyzed by the proposed chemometric methods.

\section{Methods}

Design of experiments. - This study employs a multilevel partial factorial design for five concentration levels (level $(1)=5$ ). Mutually orthogonal designs are only possible if the number of concentration levels is a prime number or a power of a prime number. The design requires at least $1^{2}$ experiments ( 25 experiments) to study a mixture. After numbering the levels from -2 (lowest) to +2 (highest), the complete design was obtained, using what is often described as a cyclic generator or permuter $(-2,-1,2,1,-2)$, a re-

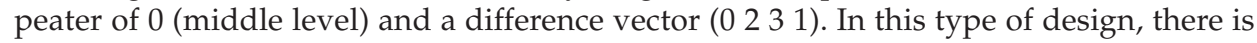
no correlation between any concentrations of the compounds between two columns, i.e., the columns are orthogonal in nature; hence, the correlation coefficient is zero.

Inverse least squares (ILS) method. - The inverse expression of the Bouguer-Beer-Lambert law in UV/Vis spectroscopy when applied to multiple linear regression leads to the 
A. S. K. Sankar et al.: Simultaneous estimation of ramipril, acetylsalicylic acid and atorvastatin calcium by chemometrics assisted UV-spectrophotometric method in capsules, Acta Pharm. 61 (2011) 283-296.

ILS method. Mathematical formulations of this method, in the matrix compact form, can be written (14) as follows:

$$
C=P \times A
$$

where $C$ is concentration matrix, $P$ is calibration coefficient and $A$ is the absorbance data matrix. Coefficient $P$ can be determined as follows:

$$
P=\left(A^{\mathrm{T}} A\right)^{-1} A^{\mathrm{T} C}
$$

Instead of finding the transpose and inverse for the large data set, the Moore-Penrose pseudo inverse (a function in the MATLAB 7.0 ver.) of the absorbance data matrix was found out (a calculation method to find out the inverse of a large data matrix). The prediction of unknown spectra $\left(a^{\mathrm{T}}\right)$ can be made with the following equation:

$$
C_{0}=a^{\mathrm{T}} \times P
$$

$C_{0}$ and $a^{\mathrm{T}}$ is the unknown sample concentration. Superscript $T$ on all the letters refers to the transpose of a matrix.

Principal component regression (PCR) method. - In the spectral work, the following steps can explain the fundamental concept of PCR: $(i)$ The original data obtained in absorbances $(A)$ is smoothed by using the Savitzky-Golay smoothing method (a function in the MATLAB 7.0 ver.) and concentration $(C)$ of the analyte is reprocessed by mean-centering as $A_{0}$ and $C_{0}$, respectively. $i$ ) The covariance dispersion matrix of the centered matrix $A_{0}$ is computed. The normalized eigenvalues and eigenvectors are calculated starting from the square covariance matrix. The number of optimal principal components (eigenvectors) is selected by considering only the highest values of the eigenvalues. The other eigenvalues and their corresponding eigenvectors were eliminated from this study. Using the ordinary linear regression (12-14):

$$
C=a+b \times A
$$

Coefficients $a$ and $b$ are calculated. To reach this objective coefficient $b$ is to be estimated first as:

$$
b=P \times q
$$

where $P$ is the matrix of eigenvectors and $q$ is the C-loading given by

$$
q=D \times T^{\mathrm{T}} \times A
$$


Here, $T^{\mathrm{T}}$ is the transpose of the score matrix $T, D$ is a diagonal matrix having on the components of the selected eigenvalues. Knowing $b$, we can easily find $a$ by using the formula:

$$
a=C_{\text {mean }}-A^{\mathrm{T}}{ }_{\text {mean }} \times b
$$

where $A^{\mathrm{T}}$ mean represents the transpose of the matrix having the mean absorbance values and $C_{\text {mean }}$ is the mean concentration of the calibration set.

Partial least squares (PLS) method. - The PLS calibration using the orthogonalized PLS algorithm developed by Wold (12-14) and extensively discussed by Martens and Naes (14) involves simultaneously the independent and dependent variables on the data compression and decomposition operations. In spectrophotometry, the PLS calibration is done by decomposition of both the concentration and absorbance matrix into latent variables:

$$
A=T P^{\mathrm{T}}+E \text { and } C=U Q^{\mathrm{T}}+F
$$

The loading vector $W$ can be expressed by the equation:

$$
W=\frac{A^{\mathrm{T}} C}{C^{\mathrm{T}} C}
$$

The scores and loadings are given by:

$$
t_{1}=A W+E, \quad P_{1}=\frac{A^{\mathrm{T}} t_{1}}{t_{1}^{\mathrm{T}} t_{1}}, \quad q_{1}=\frac{C^{\mathrm{T}} t_{1}}{t_{1}^{\mathrm{T}} t_{1}}
$$

The matrix and vector of the residuals in absorbances and concentration were found by:

$$
A_{1}=A-t_{1} P_{1}^{\mathrm{T}} \quad \text { and } \quad C_{1}=C-t_{1} q_{1}^{\mathrm{T}}
$$

From the general linear equation, the regression co-efficient was calculated by:

$$
b=W\left(P^{T} W\right)^{-1} q
$$

where $W$ is a weight matrix. Using the linear regression, the constant $a$ is calculated by

$$
a=C_{\text {mean }}-A^{\mathrm{T}} \text { mean } \times b
$$

Like in the PCR method, the PLS calibration is used for the estimation of compounds in the samples (12). 
A. S. K. Sankar et al.: Simultaneous estimation of ramipril, acetylsalicylic acid and atorvastatin calcium by chemometrics assisted UV-spectrophotometric method in capsules, Acta Pharm. 61 (2011) 283-296.

\section{RESULTS AND DISCUSSION}

\section{Calibration matrix and selection of spectral zones for analysis by ILS, PCR and PLS-1}

Fig. 1. shows the overlain zero-order spectra for RA, AS and AT ternary mixture in methanol. As shown, RA, AS and AT exhibit absorption maxima at 206, 226 and $246 \mathrm{~nm}$, respectively. The RA, AS and AT spectra are overlapped in the absorption maxima. For this reason, three chemometric calibrations, using the zero-order spectra, were separately applied to simultaneous determination of these drugs in mixtures. The absorbance matrix was obtained by measuring the zero-order absorbance in the wavelength range between 210 and $320 \mathrm{~nm}$, as shown. The quality of multicomponent analysis is dependent on the wavelength range and the spectral mode used. PLS and PCR procedures are designated to be full spectrum computational procedures; hence wavelength selection is seemingly unnecessary, and so all available wavelengths are often used. However, measurements from spectral wavelengths that are non-informative in a model degrade performance. Original and reconstructed spectra of the calibration matrix were compared in order to select the range of wavelengths along with using the root mean squared error of calibration (RMSEC), root mean squared error of cross validation (RMSECV) and root mean squared error of prediction (RMSEP) values. Besides, the regions where reconstruction of the spectrum gives the best results were also considered. The wavelength range 220-320 $\mathrm{nm}$ with 1-nm intervals was selected, since this range was providing the greatest amount of information about the three components.

\section{Training and validation set design}

A training set design of the concentration data corresponding to RA, AS and AT mixtures was organized statistically to maximize the information content in the spectra

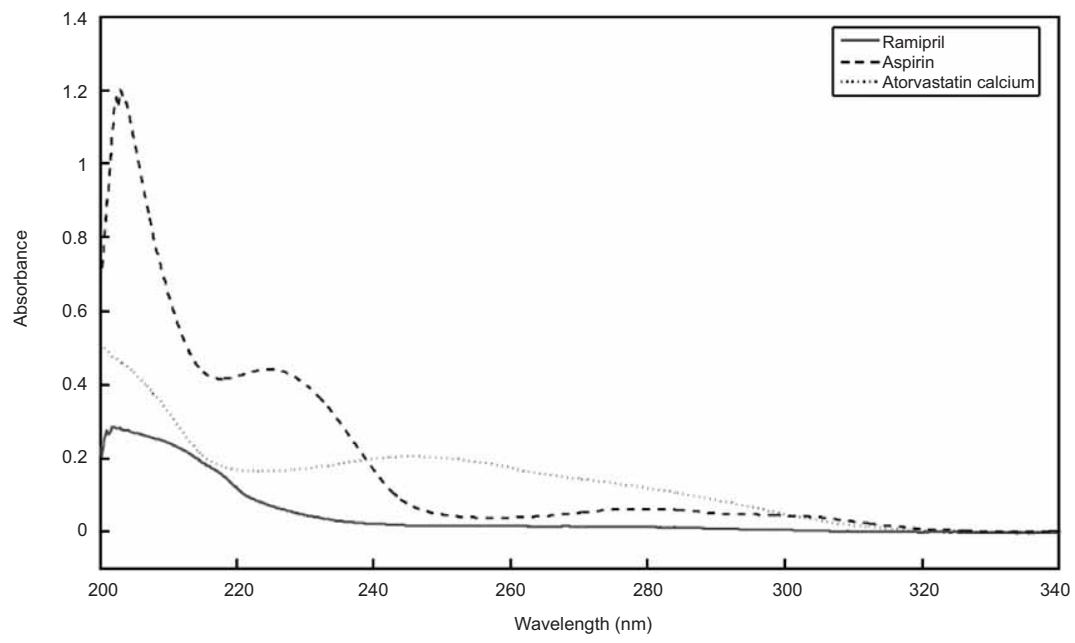

Fig. 1. Overlain spectra of ramipril, acetylsalicylic acid and atorvastatin calcium. 
A. S. K. Sankar et al.: Simultaneous estimation of ramipril, acetylsalicylic acid and atorvastatin calcium by chemometrics assisted UV-spectrophotometric method in capsules, Acta Pharm. 61 (2011) 283-296.

and to minimize the error of multivariate calibrations, as shown in Table I. The training set of 25 standard mixture solutions containing concentrations with different ratios of RA, AS and AT was prepared in the linearity range of three drugs; it is shown in Table I. To validate the developed methods, a prediction (validation) set was prepared as shown in Table II.

\section{ILS method}

In the calibration equation, the coefficient matrix $(P)$ was obtained from the linear equation system using the absorbance corresponding to the training set. Introducing $P$ into the equation system gives the ILS calibrations. Absorbance values of the samples, at the selected wavelengths in the spectral region from 210 to $320 \mathrm{~nm}$, were introduced into the obtained calibrations and the quantities of RA, AS and AT in the synthetic mixture prediction (validation) set and capsules were predicted.

\section{PCR method}

The PCR calibration was constructed using the PCR algorithm as explained earlier. The zero-order absorbances measured at selected wavelength ranges were used for calibration; they were introduced in the PCR calibrations. The quantity of each drug in the synthetic mixture prediction (validation) set and capsules were determined.

Table III. Statistical data for the prediction set by PLS 1, PCR and ILS methods

\begin{tabular}{|c|c|c|c|c|c|c|c|c|c|}
\hline \multirow{2}{*}{ Parameter } & \multicolumn{3}{|c|}{ PLS-1 } & \multicolumn{3}{|c|}{ PCR } & \multicolumn{3}{|c|}{ ILS } \\
\hline & RA & AS & AT & RA & AS & AT & RA & AS & AT \\
\hline $\begin{array}{l}\text { Wavelength } \\
\text { range }(\mathrm{nm})^{\mathrm{a}}\end{array}$ & $207-312$ & $207-312$ & $220-300$ & $207-312$ & $207-312$ & $220-300$ & $207-312$ & $207-312$ & $220-300$ \\
\hline $\begin{array}{l}\text { Linear range } \\
\left(\mu \mathrm{g} \mathrm{mL} L^{-1}\right)\end{array}$ & $1-5$ & $10-50$ & $2-10$ & $1-5$ & $10-50$ & $2-10$ & $1-5$ & $10-50$ & $2-10$ \\
\hline RMSEC & 0.047 & 0.494 & 0.190 & 0.047 & 0.177 & 0.190 & 0.040 & 0.321 & 0.124 \\
\hline RMSEP & 0.045 & 0.491 & 0.219 & 0.045 & 0.229 & 0.221 & 0.040 & 0.421 & 0.125 \\
\hline Mean (\%) & 100.00 & 100.20 & 99.79 & 100.10 & 99.84 & 99.89 & 99.65 & 99.95 & 99.71 \\
\hline RSD (\%) & 1.55 & 1.87 & 3.26 & 1.55 & 1.05 & 3.26 & 1.44 & 2.150 & 2.320 \\
\hline$R^{\mathrm{b}}$ & 0.999 & 1.000 & 0.995 & 0.999 & 1.000 & 0.995 & 1.005 & 1.000 & 0.999 \\
\hline Slope ${ }^{b}$ & 0.003 & 0.000 & 0.027 & 0.003 & 0.005 & 0.027 & -0.025 & 0.048 & -0.014 \\
\hline Intercept $\mathrm{t}^{\mathrm{b}}$ & 0.999 & 0.999 & 0.998 & 0.999 & 1.000 & 0.998 & 1.000 & 1.000 & 0.999 \\
\hline
\end{tabular}

RA - ramipril, AS - acetylsalicylic acid, AT - atorvastatin calcium

a Selection by trial and error method based on RMSECV and RMSEC.

$\mathrm{b}$ Calculated for actual and predicted values of the prediction set. 
A. S. K. Sankar et al.: Simultaneous estimation of ramipril, acetylsalicylic acid and atorvastatin calcium by chemometrics assisted UV-spectrophotometric method in capsules, Acta Pharm. 61 (2011) 283-296.

\section{PLS-1 method}

The corresponding calibration was obtained by using PLS algorithms, as explained earlier. The zero-order absorbance was measured in the same range and on the same sample as in the PCR method.

\section{Statistical analysis in selecting the number of principal components or factors}

We can define the ability of a calibration in several ways. In this subsection, we calculated the standard variation of chemometric calibrations in the case of investigated mixtures. An appropriate choice of the number of principal components or factors is necessary for PCR and PLS-1 calibrations. The number of factors should account as much as possible for the experimental data without resulting in overfitting. Various criteria have been developed to select the optimum number $(13,14)$. A cross-validation method leaving out one sample at a time was employed (15). With a calibration set of 25 calibration spectra, PLS-1 and PCR calibrations on 24 calibration spectra were performed, and using this calibration the concentration of the sample left out during the calibration process was determined. This process was repeated 25 times until each calibration sample had been left once. The predicted concentrations were compared with the known concentrations of the compounds in each calibration sample. The method developed by Haaland and Thomas (16) was used for selecting the optimum number of factors, which involves selecting that model including the smallest number of factors that result in an insignificant difference between the corresponding RMSECV and the minimum RMSECV. To validate the model, both RMSECV and RMSEP were considered; they must be as low as possible for a particular model. RMSEP were calculated for each method as follows:

$$
\begin{gathered}
\text { RMSECV }=\sqrt{\sum \frac{\left(c_{\text {act }}-c_{\text {pred }}\right)^{2}}{I_{c}}} \text { and } \\
\text { RMSEP }=\sqrt{\frac{\sum \frac{\left(y_{\text {act }}-y_{\text {pred }}\right)^{2}}{I_{p}}}{p}}
\end{gathered}
$$

where $C_{\text {act }}$ and $Y_{\text {act }}$ and $C_{\text {pred and }} Y_{\text {pred }}$ denote actual and determined concentrations of the calibration and prediction set samples, respectively. $I_{\mathrm{c}}$ and $I_{\mathrm{p}}$ are the total number of calibration and prediction set samples, respectively. The numerical values of RMSEC and RMSEP are given in Tables III and VI. By inspection we conclude that RMSEC is minimal for PLS and PCR methods for all the three drugs. RMSEP values of the same mixtures are displayed in Table III and similar behavior of the values was observed as for RMSEC. The mean recoveries and the relative standard deviations of the proposed methods were computed (Tables IV and V).

\section{Figures of merit}

Determination of figures of merit (FOM) is necessary for the validation of chemometric methods. FOM, such as sensitivity (SEN), selectivity (SEL), the inverse of 
A. S. K. Sankar et al.: Simultaneous estimation of ramipril, acetylsalicylic acid and atorvastatin calcium by chemometrics assisted UV-spectrophotometric method in capsules, Acta Pharm. 61 (2011) 283-296.

Table IV. Composition and results for the commercial formulation set by PLS1, PCR and ILS methods

\begin{tabular}{|c|c|c|c|c|c|c|c|c|c|c|c|c|}
\hline & \multirow{2}{*}{\multicolumn{3}{|c|}{$\begin{array}{l}\text { Concentration } \\
\left(\mu \mathrm{g} \mathrm{mL} \mathrm{m}^{-1}\right)\end{array}$}} & \multicolumn{9}{|c|}{ Label claim found $(\%)^{\mathrm{a}}$} \\
\hline & & & & \multicolumn{3}{|c|}{ PLS-1 } & \multicolumn{3}{|c|}{ PCR } & \multicolumn{3}{|c|}{ ILS } \\
\hline & RA & AS & $\mathrm{AT}$ & RA & AS & AT & RA & AS & AT & RA & AS & AT \\
\hline $\mathrm{F}$ & 2 & 30 & 4 & 99.8 & 99.0 & 99.8 & 98.5 & 98.7 & 98.5 & 97.4 & 98.0 & 97.5 \\
\hline R1 & 3 & 40 & 6 & 100.1 & 100.9 & 99.5 & 98.8 & 98.5 & 98.2 & 97.2 & 98.3 & 98.3 \\
\hline R2 & 4 & 45 & 8 & 100.0 & 101.1 & 100.8 & 98.7 & 98.3 & 99.5 & 99.7 & 97.9 & 96.0 \\
\hline R3 & 5 & 50 & 10 & 100.7 & 98.8 & 100.0 & 99.4 & 99.4 & 98.7 & 95.4 & 99.3 & 98.5 \\
\hline
\end{tabular}

a Mean of six determinations.

F - Commercial formulation.

R1, R2, R3 - Recovery done by the standard addition method at three levels.

analytical sensitivity $\left(\gamma^{-1}\right)$, limit of detection $(L O D)$ and limit of quantification $(L O Q)$ can be estimated and used to compare analytical methods. Sensitivity here refers to the calibration sensitivity, as it is calculated from the calibration set. It differs from analytical sensitivity, $\gamma$, the inverse of which is useful in comparing two different methods regardless of the calculation steps. When expressing FOM for multivariate calibration methods, the part of the signal that referes to the analyte is more important than the total signal. This unique signal is termed net analyte signal (NAS) and is defined as the part of the signal that is orthogonal to the signal of the interferences (other analytes) present in the sample (17). The NAS is a vector containing the values for each sample and can be

Table V. Recovery from commercial preparations by the standard addition method by PLS 1, PCR and ILS methods

\begin{tabular}{|c|c|c|c|c|c|c|c|}
\hline \multirow{2}{*}{ 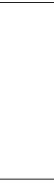 } & \multirow{2}{*}{ Drug } & \multicolumn{2}{|c|}{ PLS 1} & \multicolumn{2}{|c|}{ PCR } & \multicolumn{2}{|c|}{ ILS } \\
\hline & & \multicolumn{2}{|c|}{$\begin{array}{c}\text { Found } \\
\text { Mean } \pm \text { RSD } \\
(\%)^{\mathrm{a}}\end{array}$} & \multicolumn{2}{|c|}{$\begin{array}{c}\text { Found } \\
\text { Mean } \pm \text { RSD } \\
(\%)^{\mathrm{a}}\end{array}$} & \multicolumn{2}{|c|}{$\begin{array}{c}\text { Found } \\
\text { Mean } \pm \text { RSD } \\
(\%)^{\mathrm{a}}\end{array}$} \\
\hline \multirow[t]{3}{*}{$\mathrm{R} 1$} & RA & 99.9 & 1.1 & 99.8 & 1.2 & 99.3 & 1.2 \\
\hline & AS & 100.0 & 0.6 & 99.9 & 0.6 & 100.4 & 0.8 \\
\hline & AT & 99.8 & 0.4 & 99.7 & 0.4 & 100.4 & 2.2 \\
\hline \multirow[t]{3}{*}{$\mathrm{R} 2$} & RA & 100.4 & 1.3 & 100.3 & 1.3 & 100.1 & 1.0 \\
\hline & AS & 99.9 & 0.3 & 99.8 & 0.3 & 100.0 & 0.3 \\
\hline & AT & 99.6 & 0.8 & 99.5 & 0.8 & 98.0 & 4.3 \\
\hline \multirow[t]{3}{*}{ R3 } & RA & 100.0 & 0.2 & 99.9 & 0.2 & 99.9 & 1.3 \\
\hline & AS & 99.9 & 0.7 & 99.8 & 0.7 & 100.3 & 0.8 \\
\hline & AT & 99.9 & 0.7 & 99.8 & 0.7 & 100.6 & 1.2 \\
\hline
\end{tabular}

a Mean for six determinations.

RA - ramipril, AS - acetylsalicylic acid, AT - atorvastatin calcium.

R1, R2, R3 - Recovery done by the standard addition method at three levels. 
related to the regression vector, $b$, from any multivariate calibration model, such as PLS-1, PCR or ILS (18) by the following equation:

$$
\|N A S\|=\frac{1}{\left\|b_{k}\right\|}=S E N
$$

where the symbol \|\| means the Euclidian norm, which is defined as the square root of the squared elements of a vector. Other FOMs can be subsequently calculated as functions of the NAS (or the regression vector). The SEL is a measure, ranging from 0 to 1, of how unique the spectrum of the analyte is compared to the other species. It indicates the part of the total signal that is not lost due to spectral overlap, and can be defined in the multivariate context by resorting to NAS calculation also with reference to SEN (18):

$$
S E L=\frac{\|N A S\|_{2}}{\|X\|_{2}} \text { or } \quad S E L=\frac{S E N}{\|X\|_{2}}
$$

where the symbol $\|_{2}$ means the Euclidian norm of a vector, NAS is the net analyte signal of the corresponding analyte and $X$ is the total signal of the sample. A more informative FOM is analytical sensitivity $(\gamma)$, which is defined, in analogy with univariate calibration, as the ratio between SEN and the instrumental noise $(\varepsilon)$, according to equation:

$$
\gamma=\frac{S E N}{\|\varepsilon\|}
$$

where $\|\varepsilon\|$ is a measure of the instrumental noise. The value of $\|\varepsilon\|$ may be estimated from the standard deviation of the spectral residuals of that particular multivariate calibration model, while 0.001 was used for the ILS method. With the inverse of $\gamma\left(\gamma^{-1}\right)(18)$, it is possible to establish a minimum concentration difference that is discernible by the analytical method in the absence of experimental error. Concerning the limits of detection and quantification, the following simple equations have been proposed for their estimation:

$$
\begin{gathered}
L O D=3.3\|b\|\|\varepsilon\| \text { and } \\
L O Q=10\|b\|\|\varepsilon\|
\end{gathered}
$$

where $b$ is the regression coefficient of the selected component and $\gamma$ is the standard deviation of the errors in the spectra of the calibration model, while for the ILS model, a value equivalent to 0.001 is used as error (19).

\section{Capsule analysis}

Twenty capsules were weighed accurately and emptied into a mortar. An amount equivalent to one capsule was dissolved in methanol by sonication. The solution was filtered into a 100-mL calibrated flask through Whatman no. 42 filter paper and diluted to an appropriate volume with the same solvent. The proposed techniques were applied to the analysis of the capsule formulation, and in this case, the mean percent and standard 
A. S. K. Sankar et al.: Simultaneous estimation of ramipril, acetylsalicylic acid and atorvastatin calcium by chemometrics assisted UV-spectrophotometric method in capsules, Acta Pharm. 61 (2011) 283-296.

deviation of the label claim amount found in PLS 1, PCR and ILS methods for the commercial formulation were as follows for RA $99.7 \pm 0.8,99.6 \pm 0.8$ and $99.5 \pm 1.4$, for AS $99.7 \pm 0.4,99.6 \pm 0.4$ and $101.1 \pm 2.0$ and for AT $100.0 \pm 1.1,99.9 \pm 1.1$ and $99.6 \pm 2.4$, respectively. The results of all methods were very close to each other.

\section{Standard addition method for validation (recovery studies)}

The interference of excipients and additives for three drugs was tested by the application of the proposed methods to a commercial capsule formulation and no interference was observed according to the experimental results performed as follows. Standard solutions of pure drugs corresponding to capsule content were added to the solutions and analyzed by the PLS 1, PCR and ILS methods. In this case, the mean and standard deviation of PLS 1, PCR and ILS models was found by the standard addition method and is shown in Table VI. It can be seen from the $L O D, L O Q$ and analytical sensitivity (Table VI) that PLS 1 and PCR methods do not differ significantly. From the recovery results for each drug, it was found that no interference by the excipients was observed (Table V).

Table VI. Figures of merit for PLS 1, PCR and ILS methods

\begin{tabular}{|c|c|c|c|c|c|c|c|c|c|}
\hline \multirow{2}{*}{ Parameter } & \multicolumn{3}{|c|}{ Ramipril } & \multicolumn{3}{|c|}{ Acetylsalicylic acid } & \multicolumn{3}{|c|}{ Atorvastatin calcium } \\
\hline & PLS 1 & PCR & ILS & PLS 1 & PCR & ILS & PLS 1 & PCR & ILS \\
\hline Factors & 4 & 4 & - & 4 & 4 & - & 5 & 5 & - \\
\hline RMSEC & 0.0471 & 0.0472 & $1.823 \times 10^{-13}$ & 0.1766 & 0.1766 & $5.307 \times 10^{-12}$ & 0.1232 & 0.1265 & $1.207 \times 10^{-12}$ \\
\hline RMSECV & 0.0591 & 0.0592 & 0.0353 & 0.2323 & 0.2323 & 0.2595 & 0.1710 & 0.1751 & 0.1236 \\
\hline RMSEP & 0.0443 & 0.0447 & 0.0401 & 0.2226 & 0.2292 & 0.2928 & 0.1253 & 0.1278 & 0.1250 \\
\hline $\begin{array}{l}\text { SEN } \\
\left(\mathrm{mL} \mu \mathrm{g}^{-1}\right)\end{array}$ & 0.1633 & 0.1633 & 0.0064 & 0.1713 & 0.1713 & 0.0007 & 0.0209 & 0.0216 & 0.0025 \\
\hline SEL & 0.0200 & 0.0201 & 0.0003 & 0.0688 & 0.0800 & 0.0003 & 0.0018 & 0.0018 & 0.0002 \\
\hline $\begin{array}{l}L O D \\
\left(\mu \mathrm{g} \mathrm{mL}^{-1}\right)\end{array}$ & 0.2884 & 0.2884 & 0.4688 & 0.268 & 0.268 & 4.4008 & 0.4619 & 0.3889 & 1.2000 \\
\hline $\begin{array}{l}L O Q \\
\left(\mu \mathrm{g} \mathrm{mL}^{-1}\right)\end{array}$ & 0.9614 & 0.9614 & 1.5625 & 0.8932 & 0.8932 & 14.6692 & 1.3397 & 1.2963 & 4.0000 \\
\hline $\begin{array}{l}\gamma^{-1} \\
\left(\mu \mathrm{g} \mathrm{mL}^{-1}\right)\end{array}$ & 10.401 & 10.401 & 6.4000 & 11.196 & 11.196 & 0.6817 & 7.4643 & 7.7143 & 2.5000 \\
\hline
\end{tabular}

SEN - calibration sensitivity; SEL - selectivity, LOD - limit of detection, $L O Q-$ limit of quantitation, $\gamma^{-1}-$ analytical sensitivity

\section{CONCLUSIONS}

Three chemometric methods were applied successfully to simultaneous determination of RA, AS and AT in laboratory mixtures and pharmaceutical capsules. Model that gave lowest RMSEC values when used for predicting the unknown samples, predicted well by giving lowest RMSEP values. On the other hand, the fundamental advantages of our investigated methods are the simultaneous analysis of the mixture of the subject drugs, without chemical pretreatment, speed of analysis and cost effectiveness. Finally, 
A. S. K. Sankar et al.: Simultaneous estimation of ramipril, acetylsalicylic acid and atorvastatin calcium by chemometrics assisted UV-spectrophotometric method in capsules, Acta Pharm. 61 (2011) 283-296.

all the developed methods can be applied to the routine analysis, quality control of mixtures and commercial preparations containing these three drugs.

Acknowledgements. - One of the authors, A. S. K. Sankar, gratefully acknowledges the support from the management of the Adhiparasakthi Charitable, Medical, Educational and Cultural Trust, Melmaruvathur, for providing necessary facilities to carry out this research work. Orchid Chemicals \& Pharmaceuticals, Ltd, R\&D division, Chennai, and Prof. Dr. A. K. Mishra, IIT, Chennai, are kindly acknowledged for allowing to use their facilities.

\section{REFERENCES}

1. H. S. Malhotra and K. L. Goa, Atorvastatin: an updated review of its pharmacological properties and use in dyslipidaemia, Drugs 61 (2001) 1835-1881.

2. T. G. Warner and M. C. Perry, Ramipril: a review of its use in the prevention of cardiovascular outcomes, Drugs 62 (2002) 1381-1405.

3. P. S. Hervey and K. L Goa, Extended-release dipyridamole/aspirin, Drugs 58 (1999) 469-475.

4. J. P. Hiral, N. S. Bhanubhai, J. P. Natvarlal, S. R. Ishwarsinh and H. P. Bhavesh, Simultaneous estimation of atorvastatin calcium, ramipril and aspirin in capsule dosage form by RP-LC, Chromatographia 69 (2009) 91-95; DOI: 10.1365/s10337-008-0831-z.

5. M. Gandhimathi, T. K. Ravi and N. Shukla, Simultaneous determination of aspirin and clopidogrel in tablets by HPTLC method, Indian Drugs 43 (2006) 397-399; DOI: 10.4103/0250-474X. 32125.

6. K. Anandakumar, T. Ayyappan, V. Raghu Raman, T. Vetrichelvan, A. S. K. Sankar and D. Nagavalli, RP-HPLC analysis of aspirin and clopidogrel bisulphate in combination, Indian J. Pharm. Sci. 69 (2007) 597-599; DOI: 10.4103/0250-474X.36958.

7. A. C. Mot, F. Soponar, A. Medvedovici and C. Sârbu, Simultaneous spectrophotometric determination of aspirin, paracetamol, caffeine, and chlorphenamine from pharmaceutical formulations using multivariate regression methods, Anal. Lett. 43 (2010) 804-813; DOI: 10.1080/00032710903486260.

8. Nagaraj, K. Vipul and M. Rajshree, Simultaneous quantitative resolution of atorvastatin calcium and fenofibrate in pharmaceutical preparation by using derivative ratio spectrophotometry and chemometric calibrations, Anal. Sci. 23 (2007) 445-451; DOI: 10.2116/analsci.23.445.

9. V. P. Kurade, M. G. Pai and R. Gude, RP-HPLC estimation of ramipril and telmisartan in tablets, Indian J. Pharm. Sci. 71 (2009) 148-151; DOI: 10.4103/0250-474X.54283.

10. F. Belal, A. Al-Zaagi, E. A. Gadkariem and M. A. Abounassif, A stability-indicating LC method for the simultaneous determination of ramipril and hydrochlorothiazide in dosage forms, J. Pharm. Biomed. Anal. 24 (2001) 335-342; DOI: 10.1016/S0731-7085(00)00474-X.

11. M. E. Abdel-Hamid, Applications of spectrometric full spectrum quantitation (FSQ) software for multicomponent analysis and stability studies of pharmaceuticals, Anal. Lett. 33 (2000) 2719-2735; DOI: 10.1080/00032710008543218.

12. K. R. Beebe and B. R. Kowalski, An introduction to multivariate calibration and analysis, Anal. Chem. 59 (1987) 1007-1017; DOI: 10.1021/ac00144a001.

13. I. Murat Palabiyik, E. Dinc and F. Onur, Simultaneous spectrophotometric determination of pseudoephedrine hydrochloride and ibuprofen in a pharmaceutical preparation using ratio spectra derivative spectrophotometry and multivariate calibration techniques, J. Pharm. Biomed. Anal. 34 (2004) 473-483; DOI: 10.1016/S0731-7085(03)00578-8.

14. H. Martens and T. Naes, Multivariate Calibration, Wiley, New York, 1992.

15. A. Espinosa-Mansilla, F. Salinas and I. De Orbe Paya, Simultaneous determination of sulfadiazine, doxycycline, furaltadone and trimethoprim by partial least squares multivariate calibration, Anal. Chim. Acta 313 (1995) 103-112; DOI: 10.1016/0003-2670(95)00252-U. 
A. S. K. Sankar et al.: Simultaneous estimation of ramipril, acetylsalicylic acid and atorvastatin calcium by chemometrics assisted UV-spectrophotometric method in capsules, Acta Pharm. 61 (2011) 283-296.

16. D. M. Haaland and E. V. Thomas, Partial least-squares methods for spectral analyses. 1. Relation to other quantitative calibration methods and the extraction of qualitative information, Anal. Chem. 60 (1988) 1193-1202; DOI: 10.1021/ac00162a020.

17. A. Lorber, K. Faber and B. R. Kowalski, Net analyte signal calculation in multivariate calibration, Anal. Chem. 69 (1997) 1620-1626; DOI: 10.1021/ac960862b.

18. M. M. Sena and R. J. Poppi, N-way PLS applied to simultaneous spectrophotometric determination of acetylsalicylic acid, paracetamol and caffeine, J. Pharm. Biomed. Anal. 34 (2004) 27-34; DOI: 10.1016/j.japna.2003.08.011.

19. C. K. Markopoulou, E. T. Malliou and J. E. Koundourellis, Application of two chemometric methods for the determination of imipramine, amitriptyline and perphenazine in content uniformity and drug dissolution studies, J. Pharm. Biomed. Anal. 37 (2005) 249-258; DOI: 10.1016/j. jpba.2004.10.024.

\section{$S A \check{Z} E T A K$}

\section{Simultano UV-spektrofotometrijsko određivanje ramiprila, acetilsalicilne kiseline i atorvastatin kalcija u kapsulama primjenom kemometrijskih metoda}

A. S. KAMATCHI SANKAR, THANGARASU VETRICHELVAN i DEVASHYA VENKAPPAYA

U radu su opisane tri različite spektrofotometrijske metode za određivanje ramiprila, acetilsalicilne kiseline i atorvastatin kalcija u sirovinama i formulacijama. Preklapanje podataka kvantitativno je riješeno pomoću kemometrijskih metoda, tj. metodama inverznih najmanjih kvadrata (ILS), regresije glavnog sastojka (PCR) i djelomičnih najmanjih kvadrata (PLS). Kalibracije su postavljene pomoću matrice podataka za apsorpciju koja odgovara matrici pripadajućih koncentracija. Područje linearnosti za ramipril iznosilo je 1-5, za acetilsalicilnu kiselinu 10-50, a za atorvastatin kalcij 2-10 $\mu \mathrm{g} \mathrm{mL} \mathrm{m}^{-1}$. Matrica s apsorbancijama dobivena je mjerenjem apsorbancije nultog reda na valnim duljinama između 210 i $320 \mathrm{~nm}$. Set podataka za koncentracije ramiprila, acetilsalicilne kiseline i atorvastatin kalcija u smjesi statistički je tako organiziran da osigura maksimalnu količinu informacije u spektrima i minimalizira grešku multivarijantnih kalibracija. Primjenom odgovarajućih algoritama za PLS, PCR i ILS na snimljene spektre kalibracijskog seta dobiven je dobar model, koji je odabran na temelju RMSECV i RMSEP vrijednosti. Isti model je primijenjen i na set s predviđenim vrijednostima i na kapsule sa smjesom ove tri ljekovite tvari. Određena je srednja vrijednost povrata za komercijalnu formulaciju te ostale analitičke izvedbene značajke (kalibracijska osjetljivost, selektivnost, granica dokazivanja, granica određivanja i analitička osjetljivost). Potvrđena je primjenjliivost predloženih metoda $\mathrm{u}$ analizama lijekova $\mathrm{u}$ fizičkim smjesama i u gotovim ljekovitim oblicima.

Ključne riječi: izvedbene značajke, multivarijantna kalibracija, ramipril, acetilsalicilna kiselina, atorvastatin kalcij

Adhiparasakthi College of Pharmacy, Melmaruvathur-603319, India

School of Biotechnology (Shanmuga Arts, Science, Technology and Research Academy), SASTRA University, Thanjavur-613402, India 